\title{
Controversial topics in agroecology: A European perspective
}

\author{
Paola Migliorini ${ }^{1,2}$, Paolo Bàrberi ${ }^{1,3}$, Stephane Bellon ${ }^{1,4}$, Gaifami Tommaso ${ }^{1,5}$, \\ Vassilis D. Gkisakis ${ }^{1,6}$, Alain Peeters ${ }^{1,7}$, and Alexander Wezel ${ }^{1,8}$ \\ ${ }^{1}$ Agroecology Europe. Corbais, Belgium. \\ ${ }^{2}$ University of Gastronomic Sciences. Pollenzo, Italy. \\ ${ }^{3}$ Scuola Superiore Sant'Anna, Institute of Life Sciences, Group of Agroecology. Pisa, Italy. \\ ${ }^{4}$ INRAE. Avignon, France. \\ ${ }^{5}$ Agroecology Europe Youth Network. Corbais, Belgium. \\ ${ }^{6}$ Hellenic Mediterranean University, School of Agricultural Sciences, Department of Agriculture, Olive \& \\ Agroecological Production Systems Laboratory. Crete, Greece. \\ ${ }^{7}$ RHEA Research Centre. Corbais, Belgium. \\ ${ }^{8}$ Isara, AgroSchool for Life, Agroecology and Environment research unit. Lyon, France..
}

\begin{abstract}
P. Migliorini, P. Bàrberi, S. Bellon, T. Gaifami, V.D. Gkisakis, A. Peeters, and A. Wezel. 2020. Controversial topics in agroecology: A European perspective. Int. J. Agric. Nat. Resour. 159-173. Seven potential controversial topics in agroecology are presented and discussed from a European perspective comparing the position of Agroecology Europe (AEEU) obtained from an iterative, participatory approach with members and compared with published literature, including views from other parts of the world. The seven controversial topics are: i) use of agrochemicals; ii) small-scale and peasant farming versus larger farms; iii) technological innovations in agriculture and precision farming; iv) biotechnology and genetic engineering in agriculture; v) local and short food circuits; vi) social justice; vii) gender perspective. The analysis shows that there are diverse points of view related to geographical area and sociopolitical contexts. However, there are several convergences towards the ambition of redesigning farming and food systems, as a lever acting on several topics, and in considering agroecology with a holistic, participatory, multiactor approach for a transition that is needed.
\end{abstract}

Keywords: Agroecological practices, agroecological principles, agroecological transition, participatory approach, sustainable food systems.

\section{Introduction}

The use of the term "agroecology" has developed more strongly across Europe over the last three decades than in other parts of the world, although

Received Jun 04, 2020. Accepted Dec 18, 2020. Corresponding author: p.migliorini@unisg.it the term was already in use at the beginning of the $20^{\text {th }}$ century (Wezel \& Soldat 2009). Since the end of the $20^{\text {th }}$ century, as scientists started to use the term to refer to the application of ecological principles to agriculture, the term's scale and dimensions have grown tremendously (Wezel et al., 2009). Additionally, the definition of the term "agroecology" has evolved since the one put forth by 
Altieri (1987 and 1995) by extending the concept to include "the ecology of food system[s]" (Francis et al., 2003). Today, three elements and interpretations of agroecology as a science, a social movement and a set of practices coexist (Wezel et al., 2009). In this framework, the transition towards more sustainable food systems should include environmental, economic, social, cultural and political issues. In this regard, agroecology reflects a paradigm shift that fundamentally challenges the existing cultural and structural power dynamics of the current unfair and unsustainable food system and places the self-organization of food producers and food eaters as a means and an end (De Molina, 2013). Agroecology, in its most transformative and political version, represents a framework that is centered on the synergistic relationships between, on the one hand, people and nature and, on the other hand, knowledge and the rights of food, in addition to the decentering of profit, market, technology transfer and similar elements of "mainstream development" (Anderson et al., 2019).

The agroecological approach has become increasingly relevant in Europe, where significant environmental and social problems emerged after the intensification and industrialization of agricultural and food systems, such as the loss of biodiversity, the contamination of soils, water, and food with pesticides, the eutrophication of water bodies, the high use of antibiotics in the livestock sector, and the decline of farm numbers and farmers' revenues, which have led to serious problems for human and agroecosystem health and for rural communities.

Agroecological approaches are now mentioned and included in the EU biodiversity strategy (European Commission, 2020a) and the EU Farm to Fork strategy (European Commission, 2020b), which guide the policy and management of biodiversity, agriculture and food systems for the next decade and set targets until 2030.

Since 2014, the Food and Agriculture Organization of the United Nations (FAO) has played a strong role in facilitating the global and regional dialogue on agroecology through nine regional and international multistakeholder meetings, which culminated in the $2^{\text {nd }}$ International Symposium on Agroecology held in Rome in 2018, which brought together the lessons learned from the regional meetings (Loconto \& Fouilleux, 2019).

In 2019, the "Ten Elements of Agroecology" report was released. This was the first FAO report dealing prominently with agroecology (FAO, 2018a). Later, the HLPE report on "Agroecological approaches and other innovations for sustainable agriculture and food systems that enhance food security and nutrition" developed the concepts of the first publication (HLPE, 2019). The report defined a concise set of 13 agroecological principles and pointed out, among other things, that there has been much less investment made in research on agroecological approaches than on other innovative approaches (for the 13 principles and 10 elements, see also Wezel et al., 2020). This report placed agroecology at the forefront and illustrated topics and issues that are highly debated within agroecology and in relation to other approaches, such as sustainable intensification and climatesmart agriculture. The recognition of agroecology as one of the pathways and alternatives to develop sustainable agriculture and food systems became visible in the global policy arena with the publication of the IAASTD Report (2009) and the IAASTD + 10 report (Herren, Haerlin \& IAASTD+10 Advisory Group, 2020).

Agroecology Europe (AEEU) is an association founded in 2016 with the goal of placing agroecology high on the European agenda of the sustainable development of farming and food systems. It intends to foster interactions between actors in science, practice and social movements by facilitating knowledge sharing and action. It aims to create an inclusive European community of professionals, practitioners and citizens who are engaged in agroecology. To do this, two Agroecology Europe Fora have been organized; the first was held in 2017 in Lyon (France), and 
the second was held in 2019 in Heraklion, Crete (Greece). Each of them gathered approximately 300 multistakeholders to discuss different challenges (Wezel et al., 2018), exchange point of view and present several contributions (Gkisakis et al., 2019), involving large numbers of young agroecologists. Some controversial topics in the agroecology debate have emerged, especially in the last five years, as agroecology has become more debated in the international arena. In accordance with its intended goal of fostering Europe-wide participatory action and debate around agroecology, AEEU has engaged in an open discussion with its members on some of these topics over the last three years, with the objective of presenting a shared position. The process and outcomes of this participatory process are presented and discussed herein, along with other opinions found in the literature.

\section{Methods}

For the future development of agroecology in Europe, it is important to better identify the current fields of application and implementation, as well as the constraints and barriers that hinder broader development. The first round of discussion was based on a World Café session consisting of approximately 300 participants that was held during the $1^{\text {st }}$ Agroecology Europe Forum in Lyon, France, in October 2017, where some of these topics and issues were identified (Wezel et al., 2018b) and a first analysis of agroecology development in Europe (Nicot et al., 2018; Wezel et al., 2019b) was performed. Subsequently, to better frame the discussion, a consultation within a working group of Agroecology Europe was carried out, from which a list of seven "controversial topics" was developed and worked out in more detail. Reduced from an initial list of approximately 10 topics, the seven topics presented here represente the most important for the future development of agroecology in Europe and relate to important issues that were identified in HLPE (2019) as contested areas in agroecology by divergent perspectives.
By "controversial topics", we mean issues of key importance for the ongoing debate on sustainable agricultural and food systems, whose vision and interpretation from an agroecological perspective have not been unequivocal. A draft text for each of these topics was then presented and discussed at the $2^{\text {nd }}$ Agroecology Europe Forum in Heraklion, Greece, in September 2019, where comments and proposals were collected. In a fourth step, a second round of comments and feedback were collected via an online consultation among AEEU members, and included in the final text versions published on the AEEU website in March 2020 (AEEU, 2020).

\section{A European perspective on controversial topics in agroecology}

In the following section, we present the seven controversial topics for agroecology and how they were debated; this format is approached by not only using European perspectives but also by relating such perspectives to the literature on these topics, thereby including views from other parts of the world. The seven controversial topics are as follows:

- Use of agrochemicals;

- Small-scale and peasant farming versus larger farms;

- Technological innovations in agriculture, including digitalization, information and communication technologies (ICT) and precision farming;

- Biotechnology and genetic engineering in agriculture;

- Local and short food circuits;

- Social justice; and

- Gender perspective. 


\section{Use of agrochemicals}

Generally, industrial agriculture, also called conventional agriculture, is characterized by the intensive use of external and commercial inputs (Kremen \& Miles, 2012), while agroecology aims to reduce strongly the use of external inputs; however, the origin of these inputs (e.g., synthetic or organic) is not fully specified (Altieri, 1995; Gliessman, 2007; IPES-Food, 2016; Watts \& Williamson, 2015). Scenarios for 2050 predict that the need for chemical fertilizers and pesticides will increase in an effort to increase crop production and feed a growing world population (FAO 2018b). Certain aspects of production increase linked to conventional agriculture are also argumented within the sustainable intensification paradigm (Wezel et al., 2015; Bernard \& Lux, 2017).

With an agroecological approach, agroecosystems should be managed sustainably by fostering synergies and beneficial ecological interactions between soil, plants, livestock and other organisms occurring across multiple scales (field, farm and landscape), as well as by integrating local and traditional knowledge (Altieri, 1995, Gliessman, 2007, Wezel et al., 2020). These beneficial interactions are fostered by the diversification of practices and production systems and the implementation of agroecological practices (Wezel et al., 2014, Migliorini \& Wezel, 2017). For example, enhancing soil health is key for crop production and nutrient recycling and for disease and pest control (Bàrberi, 2019; HLPE, 2019). Other efficient nature-based strategies exist for controlling weeds, as well as livestock diseases and parasites (Bàrberi, 2019). For instance, the use of 1) cover crops is fundamental in reducing weeds as well as maintaining soil fertility, 2) extended crop rotations help to avoid pests and diseases, 3) intercropping cereals and legumes allows for the supply of nitrogen to cereals, facilitated by competitive interactions between species, and 4) targeted and timely cultivation is useful to control weeds.
To date, there are no commonly agreed rules or certification schemes regarding the use of synthetic inputs under agroecological production, although their use is highly debated. In organic farming, synthetic inputs are not allowed (for example, in Europe according to Regulation EU 2018/848), but some products can be used if they are included in a positive list (e.g., in Annex list of EC 2008). In general, synthetic substances are prohibited in organic crop and livestock production unless specifically allowed, and nonsynthetic (natural) substances are allowed for crop and livestock production unless specifically prohibited.

A first certification scheme that also deals with external input reduction is the high environmental value (HVE) scheme, which was launched by a French policy in 2011 and is considered by policy makers as a potential agroecological certification (Wezel \& David, accepted for publication).

HVE certification aims to promote farmers' engagement in environmentally benign practices. This promotion should encourage them to decrease their negative environmental impacts related to pesticide use, improve the management of fertilizers and water and enhance on-farm biodiversity conservation (Ministère de l'Agriculture, de l'Agroalimentaire et de la Forêt, 2016). This scheme is intended to be similar to organic certification and is also seen as a premium for farmers when marketing agroecological products. In April 2019, the first supermarket chain in France decided to enlarge their products with an HVE certification to favor the development of agroecology (AgroMedia, 2019).

Regarding the use of chemicals, AEEU's position is that "agroecological systems should use neither synthetic agrochemicals nor organic contentious inputs, also during the transition period towards agroecology, because in most cases the use of, e.g., pesticides or antibiotics, counteracts the ecological functions of ecosystems that agroecology aims to enhance" (AEEU, 2020). However, during the transition towards agroecological systems, there 
might be cases in which some use of agrochemicals may be required, e.g., to face unexpected pest outbreaks. In these cases, synthetic and organic pesticides with the lowest environmental impact should be used, and only where no other ecologically based solutions or agroecological techniques can be immediately implemented. These applications should be considered as oneshot treatments to face emergency situations and to complement nonchemical methods and never as stand-alone treatments (AEEU, 2020). This is because "the final goal of any agroecological system is to eliminate synthetic fertilizers and pesticides and increase resilience by enhancing the use of renewable and internal resources and through system diversification" and redesign (AEEU, 2020).

\section{Small-scale and peasant farming versus larger farms}

Smallholder farmers are still producing most of the world's food supply nowadays (Rapsomanikis, 2015; HLPE, 2019; Ebel, 2020). Family farmers are the traditional keepers of knowledge and wisdom and can help boost rural economies (Rapsomanikis, 2015; Ebel, 2020). Therefore, family farmers around the world are likely the key actors for producing food in an agroecological way (FAO, 2020). In contrast, larger farms are often seen as having a comparative advantage regarding production and economies of scale meeting the food needs of a growing population (Godfray et al., 2010).

The assertion that small farms are a priori more sustainable than large farms is not supportable, as sustainability does not depend on size but on many other factors. There is some evidence that small farms are more sustainable than large farms, but this outcome mainly depends on management strategies (e.g., less dependence on commercial inputs; the use of on-farm or regional resources such as manure and compost; diversified cropping and livestock systems; the use of landraces; high agrobiodiversity; the provision of multiple ecosystem services; less equipment and, therefore, lower fossil fuel consumption). These types of strategies are typically more frequently applied on small farms. As a consequence, agroecological management practices often increase the environmental and economic (van der Ploeg et al., 2019) sustainability of small and peasant farms. The actual farm size that defines smallscale farming varies from country to country; for example, the USDA defines small farms in the USA as farms with less than $\$ 100,000$ in value of annual production and distinguishes them from "noncommercial" farms that make less than $\$ 50,000$ per year (Ikers, 2008). Herrero et al. (2017) considered as small and medium farms those with less than 50 ha. Globally, these farms produce 51 to $77 \%$ of nearly all the commodities examined. In regions where large farms dominate, such as North America, South America, Australia and New Zealand, these farms contribute between $75 \%$ and $100 \%$, for example, of all cereal, livestock, and fruit production. In contrast, small farms ( $\leq 20 \mathrm{ha})$ produce more than $75 \%$ of most food commodities in sub-Saharan Africa, South-East Asia, South Asia, and China.

Farm size cannot be reduced to farm area. A farmer can manage important surfaces of mountain areas while being a small farmer because livestock densities and numbers on these mountain grasslands are low. In contrast, a factory farm that raises thousands of sows and piglets on less than one hectare can be considered a large farm by the number of animals and the importance of income generated.

A five-hectare vegetable marketing farm is large, for instance, while the surface is small and animals are absent. It is large because income per ha and per labor unit is important, and several people are needed for managing it. A thirty-hectare arable farm can be considered small even if it is six-fold larger than the five-hectare example in terms of surface area because income is modest and can easily be managed by a single person. 
Some authors and organizations ${ }^{1}$ have tried to use economic parameters to define small farms. Under this scheme, small farms can be identified by their small income per farm or per labor unit. This implies that small farms can never generate high income per labor unit, which is of course not an element that can attract farmers' successors or newcomers in the business.

The Peasant Confederation, which is a French alternative Farmers' Union and a member of Via Campesina, proposes, for instance, a system that is a combination of income, surface area and livestock number (Confédération Paysanne, 2016). However, this Farmers' Union considers that the definition of the small farm cannot be harmonized across Europe because the reality of agriculture diverges strongly among European countries and that every country should define small farms from its own reality.

AEEU acknowledges (AEEU, 2020) that "smallscale and peasant farming represents the vast majority of farmers worldwide and is still of great importance in Europe. These farmers play a vital role in food sovereignty and social cohesion in large parts of the world. At the same time, agroecological approaches and solutions can help larger farms escape the locks-in of specialized industrial agricultural production and initiate the transition towards diversified and truly sustainable systems. Their engagement in agroecological farming is also expected to provide agroecosystem services across wide geographical areas." Furthermore, larger farms are likely to have more chances to invest in an agroecological transition starting with only a part of the farm, without the risk of irreversible economic damage. "Either small or large, it is important that agroecological principles are applied in order to provide benefits for the environment and society while farming activities

\footnotetext{
${ }^{1}$ The French statistical system identifies small farms on an income basis.
}

are contextualized to their social and ecological environment" (AEEU, 2020).

\section{Technological innovations in agriculture}

A new phase of agriculture, supported by industry and by innovation policies in Europe and around the world, promotes the development and integration of information and communication (ICT), sensor-based and data technologies into farming activities. This new trend has recently become a mainstream narrative of innovation in agriculture, including novel high-tech approaches such as cloud computing, specialized software, drones and the Internet of Things, all of which are presented as key tools to increase yields, reduce costs and, notably, promote agricultural sustainability (Gkisakis et al., 2017). Technological innovations, either high- or low-tech, have an important role in agriculture and may create the conditions needed to develop innovative tools and provide solutions.

However, a major question is which of these technologies are acceptable in agroecology. Additionally, it should be clarified which new technologies are specifically needed to develop further agroecological production. Agroecological practices are not in opposition to ICT but need to question what the current effects of the use of these technologies are (Carolan, 2017). These new technologies are often clearly market-oriented and might be costly and thus less accessible tools for smallholder farmers and do not always pay back. The question of profitability of these technologies is central in this issue. There are increasing discussions on the contribution of these new technologies to agroecology; however, only a few scientific publications have analyzed this topic thus far, and they have used different criteria, e.g., environmental impacts during the development/production of tools and technologies, social impacts, cost-benefit analysis and economic dependency. In addition, ICT tools, including social media and e-commerce platforms, might 
play an important role in directly connecting stakeholders of the food system, such as farmers and consumers, thereby allowing them to share knowledge and experiences and create alternative food chains.

Agroecological approaches also need to focus on democratic governance, agency and knowledge systems in regard to ICT (HLPE, 2019). In particular, they need to better evaluate what is being attempted through the use of big data, by whom, and what kinds of future food systems are being fostered through their application (Madsen et al., 2016; Carolan, 2018; HLPE, 2019). Current applications are mainly developed by a highly concentrated industry that first focuses on profits, prioritizing convenience and social status with ICT use (Gkisakis \& Damianakis, 2020), rather than on the key issues of sustainable food systems, such as ecological health, political agency, human rights, diversified knowledge systems and equity.

Traditional and novel technologies are not necessarily in opposition to agroecology (AEEU, 2020). They can provide site-specific solutions and solve local issues by optimizing natural resource use. However, AEEU (2020) considers that "technological innovations, including the recent advent of digital and data-sharing tools, are not expected to be the main drivers of the transition towards agroecology and truly sustainable food systems. In particular, patented technological innovations developed with a top-down approach are unlikely to serve the purpose of agroecological systems because they clash with the participatory approach to knowledge cocreation, which is at the heart of agroecology." Only with the active engagement of farmers and other local actors in the codevelopment of ICT-based innovations (e.g., decision support systems, smartphone applications, etc.) will the creation and uptake of technological innovations be maximized, facilitating the build-up of mutual trust between scientists, technology developers and farmers. "Participatory approaches will also minimize the risk of inappropriate use of personal data and will likely provide tools at an affordable cost for small-scale farmers." Precision farming and ICT-based technologies are not in line with agroecological principles where seen only as a way to optimize the efficacy of agricultural inputs. However, these technologies might be supportive of an initial step in the transition from conventional to agroecological systems or apply fine-tuned technologies in an already redesigned system.

\section{Biotechnology and genetic engineering in agriculture}

While genetically modified organisms (GMOs) are strictly banned for ethical reasons in organic farming, there are no clear related standards in agroecology. A recent paper discusses whether genetic engineering and agroecology are compatible (Lotz et al., 2020). In particular, three grades of modification are examined, namely, cisgenic modifications to make potatoes durably resistant to late blight, the use of CRISPR/Cas to make rice resistant to bacterial blight, and transgenic Bt crops. The authors conclude that genetic engineering and agroecology certainly have synergy in the context of agroecology science components. By contrast, its acceptability may vary depending on the norms and ethical or cultural values of social movements. However, some scientists (e.g., Ceccarelli, 2014) have suggested that GMOs can only be a short-term solution, as the main weakness of GM crops is that they ignore the fundamental theorem of natural selection. Genetically modified crops belong to the category of unstable solutions to the problem of protection against pests; this is why, in the best hypothesis, they only provide a temporary solution, which in turn, as described above, creates a new problem (a resistant pest), which requires a different solution (a new GM variety), thereby creating a never-ending technological loop that is clearly unsustainable.

There is a difference between vertical resistance (i.e., the single-gene resistance providing com- 
plete crop protection) and horizontal resistance (i.e., multiple gene-linked resistance providing different degrees of protection), from a minimum to a maximum (Robinson, 2009). Horizontal resistance provides stable protection because it is beyond a pest's capacity for microevolutionary change. Consequently, new pest strains do not emerge, and if they do, they do not have a selective advantage (Robinson, 2009). This is because horizontal resistance does not represent such a strong selection in favor of new strains, as does vertical resistance.

The acceptability of biotechnologies in agroecological farming and food systems depends on their intended use (AEEU, 2020). If the use of biotechnology is in line with the principles of agroecology and sustains biodiversity-based agricultural and food systems, including their social components, it might be a valuable addition. This could include biological and molecular techniques for the screening, selection, conservation and use of germplasm/organisms suitable for agroecological farming (e.g., marker-assisted selection (MAS), quantitative trait loci (QTL) mapping, genome-wide association studies (GWAS), in vitro culture and DNA banking in gene banks). This applies to plants, animals and microorganisms of agricultural and food/feed interest. Contrary to the current form of genetic engineering, including GMOs and new plant breeding techniques, agroecological farming and food systems are based on the importance of diversified farming and food systems for agricultural sustainability that promote and increase agrobiodiversity from the soil to the territorial level, stress the importance of conservation and sustainable use of local resources, and distribute power in the hands of various actors, thereby sharing open innovation systems and valuing farmers' knowledge, food sovereignty and cultural diversity. "AEEU supports agroecological methods that provide a more sustainable way of producing healthy food, that are efficient because better adapted to local systems, more diverse, able to cope with the continuous evolution of pests and diseases without depending on chemical control and on technological 'silver bullets', and more resilient to climate change and unfavorable economic circumstances" (AEEU, 2020).

\section{Local and short food circuits}

Local and short food circuit systems have been regaining recognition and importance in the last decade (IPES Food, 2016), and they are seen as indispensable elements for building future sustainable food systems. One major goal is to reconnect producers and consumers and to create direct economic links among the partners of the economic exchange. These systems include direct sales as local food markets or communitysupported agriculture along with local food chains that could include no more than one intermediary between the producer and the consumer. Local food systems have generally been defined as systems where the production processing, trade and consumption of food occur in a defined reduced geographical area that include short supply chains characterized by a reduced length of the chain in terms of the number of stakeholders involved. (Roep \& Wiskerke, 2012; Kneafsey et al., 2013; Praly et al., 2014).

AEEU supports and defends smallholders and family farming, farmers, networks of farmers, advisors/technicians and other actors who wish to reconnect consumers, producers and rural communities with local and short food supply chains and reach out for food sovereignty (AEEU, 2020; Peeters et al., accepted for publication). Local and territorialized food systems have huge potential to build up a wealthier, healthier and more just society, and — as such — they should be prioritized through targeted regulations (AEEU, 2020). They should not just focus on local and short food chains but should embed diversity at all levels, from seed to food processing and retail. Food and retail companies need to be engaged through a regulatory process, with food companies genuinely embracing alternative business models supporting local and 
territorialized food systems, lowering the importance of intermediates, strengthening the connections between producers and consumers, promoting food quality, fair food prices, and increasing farmers' contractual power. Hybrid food networks that link conventional and alternative marketing channels can promote processes of social growth and ecological sustainability. Such networks can be enhanced through support measures such as peri-urban storage hubs, accessibility of urban and peri-urban land for agroecological farming (especially to young farmers), promotional campaigns and regional development plans for quality food.

\section{Social Justice}

Social Justice is included in the 10 FAO Elements of Agroecology as a "human and social value" and as a principle of agroecology in HLPE (2019) under "social values and diet." Although social aspects are not always included in the different interpretations of the term "agroecology", they are fully considered in the food sovereignty and political agroecology paradigm in opposition to climate-smart agriculture (González de Molina, 2013; Pimbert, 2015). The search for a sustainable food system implies a change in the current food regimen dynamics that can only come from social agents by means of institutional mediation. Within the framework of agroecology, social movements, such as La Via Campesina ${ }^{2}$, fight for peasants' rights; climate and environmental justice; access to land, water and territories in the face of land grabbing; and private appropriation of natural resources, including genetic resources. Moreover, agroecological principles encourage a reconceptualization of farm work. Farmers are continuously stimulated to develop skills and acquire valuable experiential knowledge on local ecosystems and agricultural techniques. This contributes to the development of a number of capabilities and leads to more bargaining power, facilitating self-determination. Therefore, farm work is made

${ }^{2}$ https://whyhunger.org/our-work/resources/agroecology/ more attractive to a younger generation, which is an essential factor for safeguarding the continuity of family farms (Timmermann \& Félix, 2015).

Regarding social justice, agroecology supports rural communities and revitalizes rural areas in promoting rural employment and enlarging social inclusion (AEEU, 2020). Therefore, it helps transform societies into more inclusive ones. AEEU also favors a fair distribution of the wealth produced in and by agroecological farming. This helps ensure fair prices and adequately functioning distribution systems. AEEU "supports the inclusion of young farmers and new entrants into agriculture. This implies the construction of needed support structures (land banks, access to cheap credits, mechanisms for sharing experiences, machinery, seeds and labor, etc.)." It is also important to involve and protect minorities of all kinds. There is the danger that parts of the agricultural labor force are mobilized and contracted in illegal ways and/or are extremely exploited. Such exploitation could include low wages, bad housing, and dangerous working conditions. Migrant populations especially are often the victim of such practices. AEEU is entirely opposed to these practices and will denounce them wherever they occur (AEEU, 2020). Moreover, the inclusion of disabled people in farming should be enhanced, requiring the purposeful creation of the needed conditions needed to facilitate their participation (AEEU, 2020). Overall, AEEU "defines and supports smallholders, peasant farmers and pastoralists as integral and indispensable parts of civil society."

\section{Gender perspective}

Women play a vital role in agriculture, including the maintenance of sustainable systems of production and consumption. Furthermore, they are often the guardians of biodiversity, as they are responsible for the maintenance of local seeds and local gardens and of the diversity within communities. They are also in charge of keep- 
ing traditional knowledge on local varieties and species, especially local herbs for nutrition and health. Globally, women make up almost half of the agricultural workforce. However, they face significant barriers to sustainable development in terms of lack of access to land, technical and financial assistance and other forms of support. Women and girls remain economically marginalized and comprise one of the most vulnerable groups in our societies (Timmermann \& Félix, 2015; FAO, 2020). Although feminism has been an important current in agroecological thought (Altieri \& Rosset, 2018), gender inequalities continue to be well established in the agri-food world, i.e., in fields, families and kitchens around the world. We cannot, therefore, assume that food sovereignty and peasant agroecology are already feminist by themselves (Soler Montiel, RiveraFerre \& García Roces, 2020). Proponents of food sovereignty need to address gender systematically as a strategic element of its construct and not only as a mobilizing ideology (Young Park \& White, 2015). Additionally, by analyzing the scientific literature and agroecological scientific texts from a gender perspective, it can be seen that women seem to have remained at the margins of the political aspect of the literature, which has been driven by identifying both the androcentrism of the subject's author (i.e., the scientific practices) and the androcentrism of the texts (Prévost, 2020).

Female farmers have a long history of carrying out agroecological practices (AEEU, 2020). In the first phase of the green revolution in the 1960 s, starting with the pressure caused by the industrialization of agriculture, many farmers changed to monocultures, and the diversity of produce was reduced. However, "especially female farmers often continued to grow different types of vegetables and maintained fruit trees and gardens with flowers, livestock for noncommercial use and (medicinal) herbs to ensure on-farm biodiversity, nutritious food for their families and a healthy living environment" (AEEU, 2020). In this respect, female farmers can be regarded as the guardians of seeds in holding knowledge about selecting, storing and planting them. Often, they did not want pesticides on the food they grew for their families and thus developed and implemented agroecological practices in gardens or on their farms, as well as in their communities, which are trends that continues today.

For this reason, "their work should be highlighted, and they should be recognized for this work and for their important role" (AEEU, 2020). However, in many parts of the world, female farmers have been - and in many cases still are — excluded from heritage, land, financial autonomy, and agricultural extension. "They should be offered an equal voice in all levels of public decision-making".

To ensure the next generation of agroecological farmers, "gender equity, women and LGBT rights have to be an integral part of efforts to advance agroecology." The creation of a more horizontal relationship between humans and nature is needed, but this relationship must also be established between individuals, different generations, genders and populations. This is the social biodiversity related to agroecology. AEEU further "acknowledges that there are different feminisms related to different oppressions and that practical actions can be coconstructed based on the local experiences of female peasant and small-scale farmers and their organizations" (AEEU, 2020).

\section{Overall considerations, different views and conclusions}

The aim of this paper is to discuss, understand and clarify some controversial topics within agroecology with a participatory approach. The explicit ambition is to provide a larger discussion and promote research and innovation in the sector with guidelines to be used to design future action.

Regarding the use of agrochemicals, the position of AEEU is in alignment with many studies on the development of sustainable agriculture but differs strongly in that the final goal proposed is to eliminate 
agrochemicals. This is strongly in contrast to views of conventional agriculture proponents that sustainable intensification is needed to feed the growing world population and that this can only be achieved with the indispensable use of agrochemicals.

In regard to small-scale and peasant farming versus larger farms, there are opinions that larger farms can better contribute to feeding the world in 2050, mainly because of economies of scale and higher yields. However, small farms contribute a large amount of food produced today. The major problem lies in the definition of what is a small and large farm and what they produce, with inputs and labor. The position of AEEU is therefore not on which farm size is more favorable but that it is important that agroecological principles be applied, be it on smaller or larger farms.

For technological innovations in agriculture, including digitalization, ICT, and precision farming, the position of AEEU is that they are welcome when supporting the principles and practices of agroecology.

Regarding biotechnology and genetic engineering in agriculture, AEEU is in line with the Nyéléni Declaration (2015) and food sovereignty issues regarding the protection, respect and insurance of the stewardship of biodiversity and the implementation of producers' rights to use, sell and exchange their own seeds and animal breeds. Biotechnology and genetic engineering are top-down approaches to innovation, which are often framed in terms of economic growth in a competitive global economy rather than being integrated in farmers' priorities and local, autonomous feeding systems.

Concerning local and short food circuits, social justice and gender issues, AEEU recognizes the indissoluble connection between ecological, economic, social, cultural and political dimensions of sustainability and the need to care more for vulnerable groups, as well as to strongly recognize food security aspects. If food sovereignty is to have an intellectual future within critical agrarian studies, there is a need to reconcile the inherent contradictions of the 'we are all the same' discourse, undertaking the analysis of social differences as a starting point. This approach is in contrast with the reductionist one seeing agroecology only as the application of ecological practices to agriculture, neglecting the economic and social principles and aspects of agroecology.

The participatory approach of AEEU to debating controversial topics is not an easy process. Nevertheless, it is an important way to come to a shared consensus and clarify some critical aspects of agroecology. Indeed, some topics - e.g., biotechnology and ICT - might need to be revisited in the light of fast technological progress.

\section{Acknowledgments}

This manuscript summarises the authors' intended contribution at the Workshop on Challenges for Agroecology Development for the Building of Sustainable Agri-Food Systems (CRP), which was due to take place at the Faculty of Agricultural Sciences, University of Chile, Santiago de Chile, on 11-13 November 2019, and which was sponsored by the OECD Co-operative Research Programme: Biological Resource Management for Sustainable Agricultural Systems. Although due to the circumstances the workshop did not take place as a physical meeting and contributions intended to be supported by the OECD CRP are published in this Thematic Issue.

\section{Disclaimer}

The opinions expressed and arguments employed in this manuscript are the sole responsibility of the authors and do not necessarily reflect those of the OECD or of the governments of its Member countries.

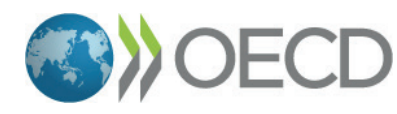




\section{Resumen}

P. Migliorini, P. Bàrberi, S. Bellon, T. Gaifami, V.D. Gkisakis, A. Peeters, y A. Wezel. 2020. Temas controversiales en la agroecología: una perspectiva europea. Int. J. Agric. Nat. Resour. 159-173. Este artículo presenta siete posibles temas controvertidos en agroecología desde una perspectiva europea que compara la posición de Agroecology Europe (AEEU) obtenida de un enfoque participativo con la literatura publicada, lo que incluye puntos de vista de otras partes del mundo. Los siete temas controvertidos son los siguientes: i) uso de agroquímicos; ii) agricultura a pequeña escala y campesina versus granjas más grandes; iii) innovaciones tecnológicas en agricultura y agricultura de precisión; iv) biotecnología e ingeniería genética en agricultura; v) circuitos alimentarios locales y cortos; vi) justicia social y vii) perspectiva de género. El análisis muestra que existen diversos puntos de vista relacionados con el área geográfica y el contexto sociopolítico. Sin embargo, hay varias convergencias.

Palabras clave: Enfoque participativo, prácticas agroecológicas, principios agroecológicos, sistemas alimentarios sostenibles, transición agroecológica.

\section{References}

AEEU. (2020). Vision and Position. Retrieved from https://www.agroecology-europe.org/our-approach/vision-of-our-organization/

AgroMedia. (2019). Leclerc fait le choix de la certification HVE pour ses fruits et légumes. Retrivede from https://www.agro-media.fr/actualite/leclerc-fait-le-choix-de-la-certification-hve-pourses-fruits-et-legumes-33117.html

Altieri, M.A. (1987). Agroecology: the scientific basis of alternative agriculture. Boulder: Westview Press.

Altieri, M.A. (1995). Agroecology: The science of sustainable agriculture. Westview Press. 433 pp.

Anderson, C.R., Bruil, J., Chappell, M.J., Kiss, C., \& Pimbert, M.P. (2019). From Transition to Domains of Transformation: Getting to Sustainable and Just Food Systems through Agroecology. Sustainability, 11(19):1-28. doi: 10.3390/ su11195272.

Bàrberi, P. (2019). Ecological weed management in sub-Saharan Africa: prospects and implications on other agroecosystem services. Advances in Agronomy, 156(4):219-264.

Bernard, B., \& Lux, A. (2017). How to feed the world sustainably: an overview of the discourse on agroecology and sustainable intensification.
Regional Environmental Change, 17(5):12791290.

Carolan, M. (2017). Publicising food: Big data, precision agriculture, and co-experimental techniques of addition. Sociologia Ruralis, 57(2):135-155.

Carolan, M. (2018). Big data and food retail: Nudging out citizens by creating dependent consumers. Geoforum, 90:142-150.

Ceccarelli, S. (2014). GM Crops, Organic Agriculture and Breeding for Sustainability. Sustainability, 6(7):4273-4286.

Confédération Paysanne. (2016). Les petites fermes sont bénéfiques pour la société, soutenons-les! Confédération Paysanne. 4 pp.

Ebel, R. (2020). Are Small Farms Sustainable by Nature? - Review of an Ongoing Misunderstanding in Agroecology. Challenges In Sustainability, 8(1):17-29. doi: 10.12924/cis2020.08010017

European Commission. (2020a). EU Biodiversity Strategy for 2030. Retrived from https:// ec.europa.eu/info/strategy/priorities-2019-2024/ european-green-deal/actions-being-taken-eu/eubiodiversity-strategy-2030_en

European Commission. (2020b). Farm to Fork Strategy - for a fair, healthy and environmentallyfriendly food system. Retrieved from https:// ec.europa.eu/food/farm2fork_en 
FAO (2018a) The 10 Elements of Agroecology: Guiding the transition to sustainable food and agricultural systems. http://www.fao.org/3/ i9037en/i9037en.pdf

FAO (2018b). The future of food and agriculture Alternative pathways to 2050. Rome. 224 p. http://www.fao.org/3/I8429EN/i8429en.pdf

FAO. (2020). Agroecology \& Family Farming. Retrieved from http://www.fao.org/family-farming/ themes/agroecology/en/

Francis, C., Lieblein, G., Gliessman, S., Breland, T.A., Creamer, N., Harwood, R., Salomonsson, L., Helenius, J., Rickerl, D., Salvador, R., et al. (2003). Agroecology: The Ecology of Food Systems. J. Sustain. Agric., 22:99-118.

Gkisakis, V.D., \& Damianakis, K. (2020). Digital innovations for the agroecological transition: A user innovation and Commons-based approach. $J$ Sustainable Organic Agric Syst., 70(2):1-4.

Gkisakis, V., Lazzaro, M., Ortolani, L., \& Sinoir, N. (2017). Digital Revolution in Agriculture: fitting in the Agroecological approach? Retrieved from www.agroecology.gr/ictagroecologyEN.html

Gkisakis, V., Bellon, S., Bàrberi, P., Migliorini, P., Peeters, A., \& Wezel, A. (2019) Scaling out, moving forward. Proceedings of the 2nd Agroecology Europe Forum, September 26-28. Heraklion, Crete, Greece. Retrieved from http:// www.agroecologyeuropeforum.eu/forum-proceedings

Gliessman, S.R. 2007. Agroecology: the ecology of sustainable food systems. CRC Press, Taylor \& Francis, New York, USA. 384 p.

González de Molina, Manuel (2013), “Agroecology and Politics. How to Get Sustainability? About the Necessity for a Political Agroecology". Agroecology and Sustainable Food Systems, 37:45-59.

Godfray, H.C.J., Beddington, J.R., Crute, I.R., Haddad, L., Lawrence, D., Muir, J.F., Pretty, J., Robinson, S., Thomas, S.M., \& Toulmin, C. (2010). Food security: the challenge of feeding 9 billion people. Science, 327(5967):812-818.

Herren, H.R., Haerlin, B., IAASTD+10 Advisory Group (eds.). (2020). Transformation of our food systems. Berlin/Zurich, Zukunftsstiftung Landwirtschaft/Biovision. Retrived from htt- ps://www.globalagriculture.org/fileadmin/files/ weltagrarbericht/IAASTD-Buch/PDFBuch/ BuchWebTransformationFoodSystems.pdf

Herrero, M., Thornton, P.K., Power, B., Bogard, J.R., Remans, R., Fritz, S., Gerber, J.S. et al. (2017). Farming and the geography of nutrient production for human use: a transdisciplinary analysis. The Lancet Planetary Health, 1(1):e33-e42.

HLPE. (2019). Agroecological approaches and other innovations for sustainable agriculture and food systems that enhance food security and nutrition. Committee on World Food Security, High Level Panel of Experts on Food Security and Nutrition, FAO Rome.

IAASTD. (2009). International Assessment of Agricultural Knowledge, Science and Technology for Development: Global Report. Eds: McIntyre, B.D., Herren, H.R., Wakhungu, J., Watson, R.T., Island Press, Washington DC, USA.

IPES-Food. (2016) From uniformity to diversity: a paradigm shift from industrial agriculture to diversified agroecological systems. International Panel of Experts on Sustainable Food systems. Retrieved from www.ipes-food.orgì

Kneafsey, M., Venn, L., Schmutz, U., Balázs, B., Trenchard, L., Eyden-Wood, T., Bos, E., Sutton, G., \& Blackett, M. (2013). Short Food Supply Chains and Local Food Systems in the EU. A State of Play of their Socio-Economic Characteristics. European Commission, Joint Research Center, Institute for Prospective Technological Studies, $129 \mathrm{p}$.

Kremen, C., \& Miles, A. (2012). Ecosystem services in biologically diversified versus conventional farming systems: benefits, externalities, and trade-offs. Ecology and Society, 17(4):40.

Lotz, L.A.P., van de Wiel, C.C.M., \& Smulders, M.J.M. (2020). Genetic engineering at the heart of agroecology. Outlook on Agriculture, 49(1):21-28. doi: 10.1177/0030727020907619

Madsen, A.K., Flyverbom, M., Hilbert, M., \& Ruppert, E. (2016). Big data: issues for an international political sociology of data practices. Int. Political Sociology, 10(3):275-296.

Migliorini, P., \& Wezel, A. (2017). Converging and diverging principles and practices of organic ag- 
riculture regulations and agroecology. A review. Agronomy for Sustainable Development. 37:63. doi: doi.org/10.1007/s13593-017-0472-4

Ministère de l'Agriculture, de l'Agroalimentaire et de la Forêt. (2016). Bio et Haute Valeur Environnementale : deux modes de valorisation complémentaires. Retrieved from https://agriculture.gouv.fr/ bio-et-haute-valeur-environnementale-deux-modes-de-valorisation-complementaires

Nicot, R., Bellon, S, Loconto, A., \& Ollivier, G. (2018). The European networks of research, education and training stakeholders in agroecology. Open Agriculture, 3:537-552. doi: 10.1515/ opag-2018-0058

Peeters, A., Lefebvre, O., Balogh, L., Bàrberi, P., Batello, C., Bellon, S., Gaifami, T., Gkisakis, V., Lana, M., Migliorini, P., Ostermann, O., \& Wezel, A. (accepted for publication) A Green Deal for implementing agroecological systems - Reforming the Common Agricultural Policy of the European Union. The Journal Landbauforschung - Journal of Sustainable and Organic Agricultural Systems.

Pimbert, M. (2015). Agroecology as an Alternative Vision to Conventional Development and Climate-smart Agriculture. Development, 58:286298. doi: 10.1057/s41301-016-0013-5

Praly, C., Chazoule, C., Delfosse, D., \& Mundler, P. (2014) Les circuits de proximité, cadre d'analyse de la relocalisation des circuits alimentaires. Géographie, Economie et Société, 16:455-478.

Prévost, H. (2020) L'agroécologie, une science «normâle»? Sous les écrits scientifiques, l'androcentrisme. In: Arrignon, M., Bosc, C. (eds.). Les transitions agroécologiques en France - Enjeux, conditions et modalités du changement. Presse Universitaires Blaise-Pascal, Clermont-Ferrand, France. Retrived from https://hal. archives-ouvertes.fr/hal-02795214

Rapsomanikis, G. (2015), Small Farms Big Picture: Smallholder agriculture and structural transformation. Development, 58(2-3):242-255. doi: 10.1057/s41301-016-0028-y.

Robinson, R.A. (2009). Breeding For Quantitative Variables. Part 2: Breeding for Durable Resistance to Crop Pests and Disease. In: S. Ceccarelli,
E. P. Guimaraes, E. Weltzien (eds.). Plant Breeding and Farmer Participation, FAO, Roma, Italy, pp. 367-390.

Roep, D., \& Wiskerke, J. (2012). On governance, embedding and marketing: Reflection on the construction of alternative sustainable food networks. Journal of Agricultural and Environmental Ethics, 25(2):205-221.

Soler Montiel, M., Rivera-Ferre, M., \& García Roces, I. (2020). The path to feminist agroecology Farming Matters. Retrieved from http:// www.cultivatecollective.org/in-perspective/ the-path-to-feminist-agroecology/

Timmermann, C., \& Félix, G.F. (2015). Agroecology as a vehicle for contributive justice. Agric Hum Values, 32:523-538. doi: 10.1007/s10460-014-9581-8 van der Ploeg, J., Barjolle, D., Bruil, J., Brunori, G., Costa Madureira, L., Dessein, J., Drąg, Z., FinkKessler, A., Gasselin, P., Gonzalez de Molina, M., Gorlach, K., Jürgens, K., Kinsella, J., Kirwan, J., Knickel, K., Lucas, V., Marsden, T., Maye, D., Migliorini, P., Milone, P., Noe, E., Nowak, P., Parrott, N., Peeters, A., Rossi, A., Schermer, M., Ventura, F., Visser, M., \& Wezel, A. (2019). The economic potential of agroecology: Empirical evidence from Europe. Journal of Rural Studies, 71:46-61. doi: 10.1016/j.jrurstud.2019.09.003

Young Park, C.M., White, B., \& Julia. (2015). We are not all the same: taking gender seriously in food sovereignty discourse. Third World Quarterly, 36(3):584-599. doi: 10.1080/01436597.2015.1002988

Watts, M., \& Williamson, S. (2015). Replacing chemicals with biology: phasing out highly hazardous pesticides with agroecology. Penang, Malaysia, PAN Asia Pacific. 208 p.

Wezel, A., Bellon, S., Doré, T., Francis, C., Vallod, D., \& David, C. (2009). Agroecology as a science, a movement or a practice. A review. Agronomy for Sustainable Development, 29:503-515.

Wezel, A., \& David, C. (accepted for publication). Policies for agroecology in France: implementation in practice, research and education and limits of impact. Landbauforschung - Journal of Sustainable and Organic Agricultural Systems.

Wezel, A., Gemmill Herren, B., Bezner Kerr, R., 
Barrios, E., Gonçalves, A.L.R, \& Sinclair, F. (2020). Agroecological principles and elements and their implications for transitioning to sustainable food systems. A review. Agronomy of Sustainable Development, 40:40. doi: 10.1007/ s13593-020-00646-z

Wezel, A., Goette, J., Lagneaux, E., Passuello, G., Reisman, E., Rodier, C., \& Turpin, G. (2018a). Agroecology in Europe: Research, education, collective action networks, and alternative food systems. Sustainability, 10:1214. doi: 10.3390/ su10041214

Wezel, A., Goris, M., Bruil, J., Félix, G.F., Peeters, A., Bàrberi, P., Bellon, S., \& Migliorini, P. (2018b). Challenges and action points to amplify agroecology in Europe. Sustainability, 10:1598. doi: 10.3390/su10051598

Wezel, A., Soboksa, G., McClelland, S., Delespesse, \& F. Boissau, A. (2015). The blurred boundaries of ecological, sustainable, and agroecological intensification. A review. Agronomy for Sustainable Development, 35(4):1283-1295. doi: 10.1007/s13593-015-0333-y

Wezel, A., \& Soldat, V. (2009). A quantitative and qualitative historical analysis of the scientific discipline agroecology. International Journal of Agricultural Sustainability, 7(1):3-18. 